\title{
PRASANGKA MAHASISWA IAIN PONTIANAK TERHADAP NON-MUSLIM
}

\author{
Samsul Hidayat
}

\begin{abstract}
Abstrak
Studi tentang pengaruh mata kuliah Perbandingan Agama dalam merubah prasangka mahasiswa Fakultas Ushuluddin, Adab dan Dakwah Institut Agama Islam Negeri (IAIN)

Pontianak sangat releven dengan kebutuhan masyarakat Kalimantan Barat yang heterogen dan multireligius. Seperti diketahui bahwa prasangka masyarakat termasuk mahasiswa muslim terhadap pemeluk agama non-Islam saaat ini masih dirasakan cukup kuat, dalam konteks stigma negatif terhadap ajaran-ajaran agama non-Islam yang dipahami secara sepihak dan penuh prejudice. Fokus penelitian ini adalah untuk mengetahui dan memahami bentuk prasangka mahasiswa Fakultas Ushuluddin, Adab dan Dakwah IAIN Pontianak, baik sebelum maupun sesudah mengikuti mata kuliah Perbandingan Agama. Untuk menjawab permasalahan tersebut, peneliti menggunakan kerangka teori prejudice atau prasangka. Pada penelitian ini menggunakan tipe penelitian deskriptif dengan metode analisis kualitatif. Sementara untuk menggali data dilakukan dengan observasi, wawancara dan kuesioner. Dalam penelitian ini yang menjadi sasaran penelitian adalah mahasiswa Fakultas Ushuluddin, Adab dan Dakwah IAIN Pontianak yang mengikuti mata kuliah Perbandingan Agama sebagai objek penelitian. Berdasarkan hasil penelitian, didapatkan beberapa hasil variasi data tentang prasangka mahasiswa sebelum dan sesudah mengikuti mata kuliah Perbandingan Agama; bahwa perubahan prasangka mahasiswa Fakultas Ushuluddin, Adab dan Dakwah IAIN Pontianak terhadap ajaran agama non Islam dapat dilihat dari pergeseran pemahaman mereka diantaranya: prasangka mahasiswa terhadap konsep ketuhanan, para nabi dan kitab suci, hari raya, dan tempat ibadah agama Kristen, Hindu, Budha dan Khonghucu. Pergeseran prasangka mahasiswa terhadap umat dan ajaran non-Islam mengalami perubahan dari prasangka yang cenderung eksklusif, dogmatis, stereotipe, perasaan frustasi karena persoalan persaingan sosial, menjadi pemahaman yang lebih terbuka, toleran, dan lebih tertarik mencari kesalingpahaman daripada mempertentangkan perbedaan.
\end{abstract}

Kata Kunci : prasangka, perbandingan agama.

\section{A. Latar Belakang}

Kekurangpahaman terhadap ajaran agama orang lain cenderung melahirkan prasangka tertentu terhadap umat tersebut. Prasangka dapat muncul baik dikalangan umat Islam terhadap umat non-muslim maupun dari umat nonmuslim kepada umat Islam. Prasangka negatif dapat melahirkan intoleransi bahkan permusuhan dan kebencian, 
berasal dari ketidaktahuan sehingga tidak mampu memahami apa yang mendasari perbuatan tertentu. Akibatnya muncul penolakan terhadap orang atau kelompok tertentu karena diyakini bahwa orang atau kelompok tersebut tidak sesuai dengan norma atau keyakinan pada umumnya.

Di lingkungan Institut Agama Islam Negeri (IAIN) Pontianak, prasangka terhadap non-muslim juga tidak bisa dihindarkan akibat minimnya wawasan pengetahuan multi agama dan interaksi dengan umat selain Islam. Dalam pengamatan peneliti, prasangka yang muncul dilingkungan mahasiswa Institut Agama Islam Negeri (IAIN) Pontianak terhadap umat non-muslim berbentuk pengetahuan yang keliru terhadap kepercayaan atau keyakinan ajaran agama selain Islam seperti Kristen, Hindu, Budha maupun Khonghucu.

Selain itu prasangka juga terlihat dari pemahaman dan prasangka buruk terhadap praktek keagamaan umat nonmuslim seperti cara berpakaian, cara berbahasa, cara beribadah, makanan dan minuman, bahkan warna-warna tertentu yang berhubungan dengan agama. Dalam survey awal terhadap sikap mahasiswa dilingkungan IAIN Pontianak khususnya Fakultas Ushuluddin Adab dan Dakwah, ditemukan indikasi ketidaksenangan atau kesalahpahaman terhadap perilaku dan ajaran-ajaran umat non-muslim yang mengakibatkan munculnya intoleransi dan permusuhan.

IAIN Pontianak sebagai salah satu perguruan tinggi Islam yang mencetak sarjana muslim diharapkan mampu mewujudkan Islam yang rahmatan lil alamin, membawa kedamaian dan kerukunan umat beragama. Hal ini seharusnya dapat diwujudkan melalui pemikiran, sikap dan perilaku yang mengedepankan kerukunan dan kedamaian dalam konteks keberagamaan.

Sesuai dengan salah satu kata kunci dari visi IAIN Pontianak yaitu Terbuka (termasuk terhadap keberagaman pemikiran dan keyakinan di masyarakat), sehingga perhatian IAIN Pontianak terhadap hal tersebut telah dan terus diwujudkan dalam suatu strategi tertentu dalam rancang kurikulum yang mendukung keluaran (out put) mahasiswa yang mampu memahami keyakinan dan perilaku umat non Islam sehingga melahirkan kerukunan dan kedamanaian.

Kurikulum yang dimaksud saat ini telah diterapkan oleh Fakultas Ushuluddin, Adab dan Dakwah yang mencantumkan mata kuliah Komunikasi Lintas Agama/Perbandingan Agama 
sebagai salah satu mata kuliah fakultas yang diajarkan di seluruh jurusan di fakultas tersebut. Mata kuliah Komunikasi Lintas Agama/Perbandingan Agama diajarkan oleh dosen-dosen kompeten IAIN Pontianak yang berdisiplin IImu Perbandingan Agama sehingga out put dari mata kuliah tersebut diharapkan mampu merubah prasangka negatif mahasiswa IAIN Pontianak terhadap nonmuslim di masyarakat. Melalui sistem perkuliahan yang berbasis KKNI, mahasiswa mendapat muatan teori dan praktek sekaligus kemampuan berinteraksi dengan umat non-muslim melalui bahan ajar yang mendukung tujuan tersebut.

\section{B. Penyebab Munculnya Prasangka Mahasiswa terhadap ajaran agama Non- Islam}

Pemahaman maupun prasangka mahasiswa Fakultas Ushuluddin, Adab dan Dakwah yang telah mengikuti mata kuliah Perbandingan Agama di IAIN Pontianak mengalami perubahan signifikan setelah peneliti melakukan post test pada pertemuan terakhir. Meskipun ada beberapa mahasiswa yang belum begitu memahami secara utuh konsep keagamaan non-Islam, namun sebagian besar mahasiswa peneliti anggap telah mengalami perubahan pemahaman yang jauh lebih baik.
Jika peneliti telusuri beberapa penyebab munculnya prasangka mahasiswa, dan dihubungkan dengan pengaruh mata kuliah Perbandingan Agama, maka dapat dianalisa beberapa aspek sebagai berikut:

1. Ketika prasangka dihubungkan dengan konteks lingkungan dimana mahasiswa tinggal, maka prasangka terhadap agama selain Islam lebih sering tampak sebagai upaya menjelaskan agama lain hanya dari segi kelemahan jika dibandingkan dengan agama Islam. Munculnya persangkaan bahwa agama selain Islam memiliki kekeliruan konsep; baik sejarah maupun ajarannya karena kebanyakan mahasiswa lahir dari kondisi lingkungan yang tidak memberikan pemahaman yang cukup tentang agama selain Islam. Hal ini terlihat dari beberapa mahasiswa yang mencoba memberikan penjelasan tentang ketuhanan agama Kristen dari sudut pandang Islam. Alih-alih memberikan uraian yang benar tentang konsep ajaran agama lain, mahasiswa justru memperkuat kebenaran dari sudut pandang agamanya sendiri.

Setelah mahasiswa mengikuti mata kuliah Perbandingan Agama baik di dalam maupun luar kelas melalui studi 
banding ke beberapa tempat ibadah dan berdialog dengan tokoh-tokoh agama seperti Kristen, Hindu, Budha dan Khonghucu, perubahan cara pandang dan wawasan mahasiswa terlihat jelas, baik dari sumber informasi dan pengetahuan yang didapatkan mereka, maupun tingkat pemahaman yang lebih baik.

2. Dengan demikian mahasiswa tidak berpretensi untuk mencari kambing hitam dari kemungkinan adanya kelemahan yang dimiliki umat Islam misal dalam hal penyebaran agama umat non Islam yang cenderung lebih serius dan massif. Hal ini disebabkan pemahaman yang muncul dari pemikiran mahasiswa bahwa adanya upaya misi penyebaran agama dari umat non Islam, bukan hanya dipahami sebagai upaya yang serius dari pihak luar dalam menyebarkan agama mereka, namun lebih disebabkan karena lemahnya umat Islam atau organisasi Islam dalam memelihara dan menjaga aqidah umat Islam agar tidak mudah tergoda dengan tawaran yang bersifat material.

3. Jika dihubungkan dengan tipe-tipe prasangka, maka apa yang dialami oleh mahasiswa FUAD IAIN Pontianak menggambarkan sebuah kondisi aversive, dalam hal ini pada umumnya mahasiswa masih dapat berinteraksi dengan umat selain Islam, namun pada kenyataannya mereka tetap berusaha untuk tidak terlalu jauh berhubungan dengan non-Muslim. Hal ini dapat ditemukan dari penjelasan sebagian besar mahasiswa bahwa mereka tidak memiliki teman nonMuslim, meski kalaupun ada, bukan sebagai teman dekat, dan jumlahnya tidak banyak. Sebagian kecil dapat ditemukan mahasiswa yang memiliki tipe ambivalent, dalam hal ini ada yang mengekspresikan perasaan negatif mereka dengan melakukan "perlawanan tersembunyi" seperti memboikot berbelanja di toko nonMuslim, namun merasakan kekhawatiran akan efek negatif yang ditimbulkan dari sikap tersebut. Sejauh penelitian ini dilakukan, peneliti tidak menemukan adanya mahasiswa yang memiliki tipe dominative.

\section{Perubahan Prasangka Mahasiswa sebelum dan sesudah mengikuti Mata Kuliah Perbandingan Agama.}

Perubahan prasangka mahasiswa Fakultas Ushuluddin, Adab dan Dakwah IAIN Pontianak terhadap ajaran agama non Islam setelah mengikuti mata kuliah Perbandingan Agama/Komunikasi Lintas Agama dapat 
dilihat dari pergeseran pemahaman mereka diantaranya sebagai berikut:

a. Pemahaman mahasiswa FUAD IAIN Pontianak terhadap para nabi dan kitab suci agama selain Islam menampakkan perubahan signifikan dan lebih merujuk pada sumber asli ajaran non Islam. Hal ini terlihat dari perubahan pemikiran mahasiswa tentang orisinalitas kitab suci agama lain yang pada awalnya dianggap sudah tercemar dan mengalami perubahan dan tidak orisinil lagi. Sebagian besar mahasiswa memberikan pandangan bahwa kitab suci tiap agama memiliki nilai kesucian dan keaslian sesuai kepercayaan penganutnya masing-masing. Bagi kitab suci Kristen, Al-Kitab tidak lagi dipandang sebagai "kitab buatan" Paulus atau kitab yang diperbaharui dari Perjanjian Lama menjadi Perjanjian Baru, tapi dipahami sebagai kitab yang memang dikarang oleh beberapa rasul seperti Matius, Markus, Lukas, Yahya dan Paulus, namun bagi umat Kristen hal tersebut tidak lalu menjadikan kitab tersebut asli atau palsu, karena pemahaman kitab dalam Islam dan Kristen memang berbeda. Jika dalam Islam kitab berasal dari Tuhan langsung, sedangkan dalam agama Kristen, kitab suci merupakan kitabnya para nabi yang telah mendapat petunjuk Tuhan.

b. Begitupun pemahaman mahasiswa tentang kitab suci agama Budha telah berubah dan lebih tepat ketimbang sebelumnya menyebut bahwa kitab suci agama Buddha adalah Taurat, Sutta, dan atau Zabur. Bahkan pada awalnya sebagian besar mahasiswa mengatakan tidak ada kitab suci dalam agama Buddha dan juga tidak mengetahui nama kitab suci agama Buddha. Kitab suci agama Budha dipahami sebagian besar mahasiswa dengan sebutan Tripitaka, atau tiga kerangjang (hikmah) yang terdiri dari sutta pitaka, yang berisi himpunan ajaran atau khutbah Budha Gautama; vinaya pitaka yang berisi peraturan tata hidup anggota biara; dan abidhamma pitaka yang berisi himpunan prosa pemikiran dan prosa kesadaran.

c. Perubahan prasangka mahasiswa juga terdapat pada pemahaman mereka tentang tempat ibadah. Misalnya jika sebelumnya mereka menyangka bahwa tempat ibadah agama Hindu berbentuk bebatuan, bahkan ada yang tidak tahu nama tempat ibadahnya, setelah mereka melakukan outing class di tempat- 
tempat ibadah, para mahasiswa baru menyadari kekeliruan pengetahuan dan pemahaman mereka tentang nama tempat ibadah, termasuk proses ritual di dalamnya.

d. Stigma dan prasangka mahasiswa terhadap hari raya umat non Islam juga mengalami perubahan dan perbaikan. Salah satu yang cukup serius dan mengandung aspek afektif (emosional) adalah prasangka mahasiswa bahwa pada perayaan ibadah Kristen yaitu pada misa Natal ada kegiatan berhubungan intim antara pastor dengan suster. Hal ini selalu dijadikan media untuk memojokkan agama Kristen yang dianggap mengalami penyimpangan karena di dalam Islam tidak diajarkan hidup melajang (selibat). Perbuatan mesum tadi dipercaya oleh sebagian mahasiswa sebagai efek atau akibat dari peraturan larangan menikah bagi seorang pelayan Tuhan seperti pastor maupun suster, namun diberikan kesempatan untuk melampiaskannya secara tersembunyi di waktu dan tempat tertentu karena mahasiswa pernah mendengar adanya kuburan bayi massal di belakang tempat ibadah Kristen yang mahasiswa sendiri tidak tahu dimana alamat gereja tersebut. Pada akhirnya mahasiswa menyadari bahwa isu tersebut masih simpang siur dan sulit dibuktikan, namun dipahami sebagai perbuatan yang tidak mungkin dilakukan oleh pelayan Tuhan kecuali secara ilegal.

\section{Proses terjadinya prasangka} sosial, termasuk prasangka mahasiswa FUAD IAIN Pontianak terhadap agama selain Islam melibatkan berbagai hal didalamnya. Pertama, adanya sikap eksklusifitas mahasiswa yang merasa agama mereka lebih baik dari agama manapun, mengakibatkan munculnya pengelompokkan sosial yang stigmatif; anda kelompok/agama yang salah, dan kami yang benar. Pengelompokkan sosial yang stigmatif dan penuh prejudise hanya akan melahirkan kekerasan pemikiran dan truth claim yang jarang sekali menemukan titik kesepahaman, jika tidak malah permusuhan dan intoleransi. Hal ini terlihat dari dialog peneliti kepada mahasiswa pada awal perkuliahan yang secara jelas hanya memetakan keyakinan sebagai salah dan benar, surga dan neraka, tanpa melihat aspekaspek lain yang lebih tinggi dan yang masih dapat dikompromikan dalam menata kehidupan sosial yang lebih sejuk dan damai.

Kedua, munculnya kompetisi sosial mahasiswa karena merasa lebih unggul dan lebih benar dari agama lain. 
Pada beberapa kasus, peneliti menemukan dalam sesi diskusi dimana mahasiswa terlihat ingin memojokkan bahkan cenderung menghina ajaran agama lain. Misalnya ada mahasiswa yang menyatakan sebagai berikut; "itu agama yang menyembah hantu yang dikiranya tuhan." Atau ada ungkapan lain seperti; "kitab mereka kan ndak ada yang asli, sudah tercemar dan dibuat-dibuat." Ada lagi yang menyatakan sebagai berikut; "kalau mereka kan hanya bermodal sebungkus indomie, yang penting masuk agama mereka," dan berbagai pernyataan lain yang cenderung memojokkan. Pada konteks ini, mahasiswa ingin menunjukkan keunggulan agamanya sendiri, tapi dengan menyudutkan ajaran agama lain. Mahasiswa cenderung melakukan penilaian terlalu ekstrim dan dibesarbesarkan terhadap kelompok lain.

Ketiga, jika dihubungkan dengan sumber-sumber prasangka, maka akibat adanya pengaruh pengetahuan dan pengalaman masa lalu, stereotipe dan prasangka terhadap umat lain memunculkan sikap mudahnya mahasiswa menggeneralisir perilaku kelompok lain sama dengan apa yang mahasiswa nilai selama ini. Terutama stereotipe dan prasangka yang negatif yang mengakibatkan renggangnya komunikasi dan interaksi mahasiswa dengan umat beragama lain. Beberapa mahasiswa menyatakan segan dan enggannya mereka berkomunikasi dengan pemeluk agama lain karena faktor yang tidak bisa mereka jelaskan penyebabnya. Mereka hanya merasa bahwa berkomunikasi dan berinteraksi dengan pemeluk agama lain hanya akan mendatangkan gangguan keimanan, kesia-siaan dan bahkan dikhawatirkan akan menjadi objek konversi ke agama lain.

Keempat, dalam konteks aspek prasangka sosial, beberapa kegiatan diskusi dengan mahasiswa memunculkan satu kecenderungan adanya perasaan frustasi mahasiswa karena persoalan persaingan sosial. Mahasiswa yang tinggal di wilayah yang banyak komunitas Tionghoa biasanya berada pada posisi sosial ekonomi yang lebih rendah dibandingkan dengan umat lain yang lebih mapan dan makmur secara ekonomi. Secara sosial, mahasiswa dihinggapi prasangka yang diekspresikan dengan ungkapan mengejek atau menyudutkan umat non Islam sebagai umat yang tidak mengetahui ajaran agama, dimana segala macam cara dilakukan, tidak peduli mana halal atau haram, yang penting mereka untung dan kaya. Dalam konteks ini mahasiswa 
cenderung mencari objek pengganti dalam mengekspresikan frustasinya kepada objek lain melalui sikap meremehkan dan tendensius. Dalam konteks konatif, beberapa "tindakan balasan" dilakukan mahasiswa dengan "memboikot" aktifitas dagang atau kerjasama bisnis dengan umat lain seperti mahasiswa tidak mau berbelanja dan membeli barang yang dijual oleh umat non Islam.

Kelima, faktor yang cukup dominan dari tumbuhnya sikap prasangka mahasiswa terlihat dari adanya dogmatisme atau kepercayaan yang diyakini sebagai sesuatu yang absolut dan mutlak kebenarannya. Pada sisi tertentu, dogmatisme melahirkan sikap intolerir dalam pemikiran, perkataan dan perbuatan mahasiswa. Mahasiswa merasa apa yang diyakini sudah final dan tidak bisa dikompromikan dengan pandangan yang lain yang pasti salah dan berbeda dengan keyakinan yang mahasiswa anut. Hal ini menjadikan sebagian mahasiswa merasa tidak perlu memberikan ruang dialog pada agama lain.

Pada satu sesi diskusi yang peneliti sebut sebagai "Debat Agama", dimana peneliti membagi mahasiswa dalam dua kelompok; kelompok Islam dan kelompok non Islam. Peneliti meminta mahasiswa mendiskusikan satu tema tertentu dan mereka diharuskan mempertahankan kelompok (konsep ajaran) yang sudah disepakati. Pada diskusi tersebut, perdebatan yang dilakukan mahasiswa kelompok Islam menunjukkan tipe Dominative Individu, dimana mahasiswa kelompok Islam cenderung lebih agresif pada target prasangka atau kelompok agama lain. Kecenderungan tipe dominative individu terlihat dari hampir seluruh sesi diskusi "Debat Agama", baik antara kelompok Islam dengan Kristen atau kepada kelompok Hindu, Budha dan Khonghucu. Peneliti belum menemukan tipe ambivalent individu maupun tipe aversive individu mahasiswa pada sesi diskusi tersebut, sampai menjelang berakhirnya perkuliahan. Sebelum perkuliahan berakhir, mahasiswa melakukan outing class dibeberapa tempat ibadah dan berdiskusi dengan para tokoh agama. Pada sesi outing class, meskipun mahasiswa sudah diarahkan untuk tidak melakukan debat kusir, peneliti tetap mengijinkan mahasiswa untuk mendiskusikan secara kritis beberapa konsep ajaran agama non Islam. Namun perbedaan kontent diskusi terlihat jelas ketika mahasiswa mampu memberikan respon dan tanggapan yang lebih matang tentang sebuah topik yang didiskusikan. 
Salah satu contoh seperti perdebatan tentang konsep Trinitas tidak lagi menjadi sebuah topik dangkal dan sarkastik bahwa tuhan memiliki anak dan mempunyai sifat seperti manusia, namun telah menjadi kajian mendalam misalnya tentang sebuah kesepahaman perbandingan antara Yesus sebagai Firman Tuhan dan Al-Quran sebagai Kalam Ilahi.

Upaya Fakultas Ushuluddin, Adab dan Dakwah IAIN Pontianak dalam meningkatkan kesadaran dan kedewasaan pemahaman agama melalui mata kuliah Perbandingan Agama, adalah bagian dari pengimplementasian visi IAIN Pontianak yang mengedepankan keterbukaan dalam kajian keislaman, sehingga diharapkan prasangka sosial yang dialami mahasiswa IAIN Pontianak semakin berkurang dan menghilang.

Mata kuliah Perbandingan Agama terbukti memberikan efek pencegahan (preventif) sekaligus efek kuratif, dalam hal ini mahasiswa dikondisikan untuk selalu menghormati perbedaan keyakinan di masyarakat, mendorong mereka untuk dapat bersosialisasi secara wajar tanpa prejudise, sekaligus menyadarkan mahasiswa untuk tidak melakukan hal-hal yang dapat merusak kerukunan dan perdamaian antar umat beragama. Jika selama perkuliahan masih ditemukan adanya unsur prasangka dari sebagian kecil mahasiswa, peneliti tetap berupaya menyadarkan dengan cara meyakinkan mahasiswa pada tujuan sesungguhnya agama diciptakan dan diperintahkannya manusia untuk beribadah adalah agar dapat menunjukkan sisi terbaik (taqwa) dalam dirinya dan terus berlomba-lomba dalam meraih kebaikan dan kejayaan.

\section{Kesimpulan}

Berdasarkan temuan dan paparan penelitian di atas, maka dapat disimpulkan beberapa hal sebagai berikut:

1. Prasangka mahasiswa Fakultas Ushuluddin, Adab dan Dakwah IAIN Pontianak sebelum mengikuti mata kuliah Perbandingan Agama, menggambarkan keyakinan dan umat non Islam seperti agama Kristen, Hindu, Budha dan Khonghucu dalam suatu variasi pemahaman yang eksklusif, dogmatis, stereotipe, dan cenderung menyudutkan. Hal ini disebabkan kuatnya pengaruh lingkungan sosial dimana mahasiswa tinggal dan pendidikan serta wawasan keagamaan yang memberikan sedikit ruang bagi pertemuan konsep-konsep ajaran dan komunikasi antar umat beragama di lingkungan mahasiswa 
berada. Temuan penelitian ini peneliti peroleh dari pre test mata kuliah Perbandingan Agama di Fakultas Ushuluddin, Adab dan Dakwah IAIN Pontianak, dan selama perkuliahan tersebut berlangsung.

2. Pada akhir perkuliahan baik dalam maupun outing class, hasil diskusi kelas dan post test menunjukkan adanya perubahan signifikan prasangka mahasiswa dalam menilai konsep ajaran agama non-Islam seperti Kristen, Hindu, Budha, dan Khonghucu. Meskipun ada beberapa mahasiswa yang belum begitu memahami secara utuh konsep keagamaan non-Islam, namun sebagian besar mahasiswa peneliti temukan telah mengalami perubahan penilaian dan pemahaman ajaran kearah yang lebih baik.

\section{E. Daftar Pustaka}

Abdullah, Irwan, 2002, Metode Penelitian Kualitatif, Hand out, Yogyakarta, Magister Administrasi Publik UGM. Ahmadi, Abu dkk, 2002, Psikologi Sosial, Jakarta, Rineka Cipta. , 2010, Perbandingan

Agama, Yogyakarta UIN Press.

Allport, G. W, 1954, The Nature of Prejudice, Cambridge, MA, Perseus Books.
Azwar, S. 2010, Penyusunan Skala Psikologi (Cetakan XIII), Yogyakarta, Pustaka Pelajar.

Brigham, J. 1986, Social psychology, Boston: Little, Brown \& Co.

Fox, James, 1982, "Dimensi Waktu dalam

Penelitian Sosial: Suatu Studi Kasus di Pulau Roti", dalam Koentjaraningrat dan Donald $\mathrm{K}$. Emmerson (ed.) Aspek Manusia dalam Penelitian Masyarakat, Jakarta, Gramedia.

Fraser, Colin, Brendan Burchell, 2001, Introducing Sosial Psychology, Cambridge: Polity Press.

Gerungan, W.A., 1998, Psikologi Sosial, Bandung, PT Eresco.

Hanurawan, Fattah, 2010, Psikologi Sosial suatu pengantar, Bandung, Remaja Rosdakarya.

Handes, 2014, Napak Tilas STAIN Pontianak ke IAIN Pontianak, Pontianak, IAIN Press.

Hogg, M.A \& Vaugan, G.M, 2002, Introduction to Social Psychology (3 $\left.3^{\text {rd }} \mathrm{Ed}\right)$, New South Wales, Pearson Education.

Hornsey, M.J. \& Hogg, M.A, 2000, Assimilation and Diversity, An Integrative Model of Subgroup Relation, Personality and Social Psychology Review, 4. 
Hudaniah, Tri Dayakisni, 2001, Psikologi Sosial, Malang: UMM Press.

Hudayana, Bambang, 1992, Pengumpulan dan Analisis Data dalam Penelitian Etnografi, dalam Jurnal Penelitian Agama, No. 2 September-Desember.

Jirhanuddin, 2012 Perbandingan Agama (Pengantar Studi Memahami Agama-agama)

Mar'at, 1981, Prasangka, Bandung, Penerbit Fakultas Psikologi UNPAD.

Myers, D. G. 1996, Social Psychology, USA, McGraw Hill,Inc.

Moloeong, Lexy, 2002, Metodologi Penelitian Kualitatif, Bandung, Remaja Rosdakarya.

R. Baron \& W. Graziano (eds), 1991, Social Psychology, $2^{\text {nd }}$ and, New York, Holt, Rinehart, and Winston.
Samovar, Larry A \& Richard E Porter, 1981, Intercultural Communication: A Reader (5th Edn.). (Belmont, CA: Wadsworth.

Sears, David O. Dkk, 1994, Psikologi Sosial, Jakarta, Erlangga. Sou'yb, Yoesoef, 2011, Agama-Agama Besar di Dunia, Yogyakarta: Pustaka Pelajar.

Spradley, J, 1972, 1997, Metode Etnografi, Yogyakarta, Tiara Wacana.

Tanggok, Ihsan, 2009, Mengenal lebih dekat Agama Khonghucu di Indonesia, Jakarta: Gramedia

Walgito, Bimo, 2003, Psikologi Sosial, Yogyakarta, Cv. Andi Ofset.

Watson, D.L,Tregerthan, G.B, \& Frank, J, 1984, Social Psychology, Science and Application, Illionist: Scots, Foresmen and co. 